\title{
Julian Bond, David Penniman to speak at ACRL National Conference
}

\section{Cultural diversity, research agenda key topics at conference.}

ivil rights activist Julian Bond, and W. David

Penniman, president of the Council on Library Resources, Inc., will speak at the ACRL Sixth National Conference, April 1214,1992 , in Salt Lake City, Utah.

Since his college days, Julian Bond has been an active participant in the movements for civil rights, economic justice, and peace, and an aggressive spokesman for the disinherited. As an activist who has faced jail for his convictions, as a veteran of more than 20 years of service in the Georgia General Assembly, as a writer, teacher, and lecturer, Bond has been a leader of so-

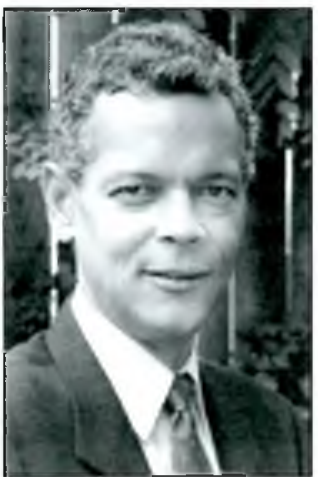

Civil rights activist Julian Bond will discuss cultural diversity at ACRL's 6th National Conference. cial change since he was a college student leading sit-in demonstrations in Atlanta in 1960.

As a student at Morehouse College, Bond joined several hundred students from across the South to help form the Student Nonviolent Coordinating Committee (SNCC) and became SNCC's communications director. Bond worked on voter registration drives in rural Georgia, Alabama, Mississippi, and Arkansas.

Bond was first elected to the Georgia House of Representatives in 1965, but members of the House voted not to seat him because of his outspoken opposition to the war in Vietnam. In 1966 the United States Supreme Court ruled unanimously that the Georgia House had violated Bond's rights in refusing toseat him.

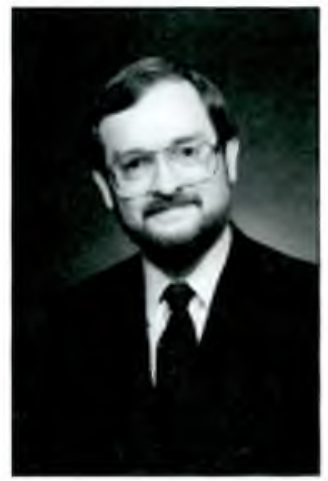

W. David Penniman will outline a research agenda for graduate and research libraries at the conference. Bond was elected to the State Senate in 1974. When he left the office in January 1987 , he had been elected topublic office more times than anyotherblack Georgian, living or dead.

Bond received a bachelor of arts degree from Morehouse College and holds honorary degrees from 14 schools. His teaching experience includes visiting professorships at Drexel University, Harvard University and the University of Virginia. His essays, articles, and poems have been widely published and he has served as a radio and television commentator.

W. David Penniman is president of the Council on Library Resources, Inc., a not-for-profit operating foundation committed to funding projects that enhance library operations. Its focus has been on major research libraries, but its scope includes a wide range of library activities including management, technology, and economic issues.

(continued on page 515) 

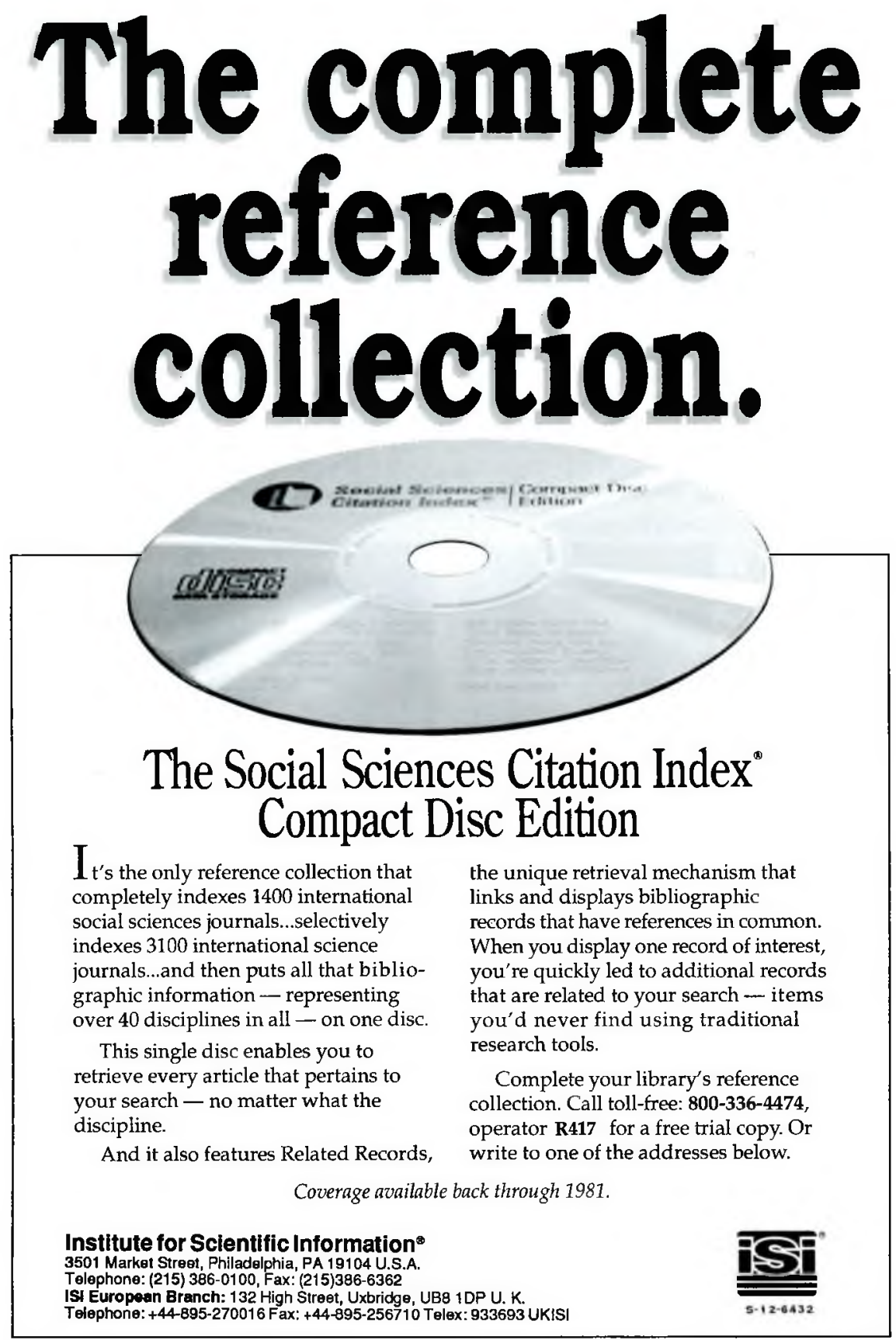

The ISI Indexes...Gateway to the Literature of the Social Sciences 
from Dominican College, New Orleans, and a master of library service degree from the University of Alabama. She is currently serving as vice-chair/ chair-elect of the Louisiana ACRL chapter.

\section{New assistant editors of $C \cup R L$ News named}

Pam Spiegel has been named assistant editor of $C \& R L$ News and will be responsible for production and layout of the magazine, as well as all copyediting and proofreading. She will also be responsible for layout and production of Rare Books and Manuscripts Librarianship. Spiegel has been an ALA employee for five years, beginning as a production assistant for $A \mathrm{~L} A$ Books, then becoming editorial assistant for C\&RL News, where she worked for ayear in 198889 before leaving to have a baby (a girl named Julia). She has also done



Pam Spiegel extensive freelance editorial work for many ALA departments, and for several other Chicago-area publishers.

Ted Bales has been named classified ads man-

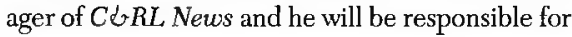

the flow of all ad copy, layout, and billing. He has worked at C\&RL News for over a year as editorial assistant. Bales is also a professional actor who is currently starring in two Chicagoproductions: the innovative, audienceparticipation piece called Too Much Light Makes the Baby Go Blind, and a new two-act comedy called Portraitof a Shiksa. He also appeared in the Hollywood film My Bodyguard.

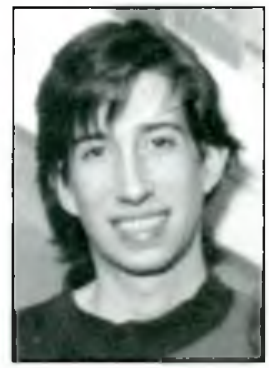

Ted Bales
Both Spiegeland Bales are half-time employees sharing the position last held by Karen Christopher, who left in May.

\section{Former ACRL staffer Nelson to direct OLOS}

Mattye L. Nelson, formerly education officer for $A C R L$, is the new director of the Office for Library Outreach Services (OLOS). Her appointment was effective on July 15, 1991. OLOS promotes the provision of library service to the urban and rural poor and to those who may be discriminated against, encourages the development of special materials for such service, and supports librarians in developing effective outreach programs.

(continuedfrompage 511)

Before joining the Council in 1991. Penniman served as director of Information Services Group and, prior to that, as libraries and information systems director at AT\&T Bell Laboratories. He has served as vice president for planning and research for OCLC, where he also established the Research Department in 1978. He has worked as a research scholar at the International Institute for Applied Systems Analysis in Austria and as an information scientist at the Battelle Memorial Institute in Columbus, Ohio, where he was also associate manager of the Information Systems Section responsible for the development of the BASIS online retrieval and data management system.

His professional activities include being chairman of the board of Engineering Information, Inc., and past-president of the American Society for Information Science. He is a senior member of the Institute of Electrical and Electronics Engineers and is a member of ALA, the Special Libraries
Association, and the Association for Computing Machinery.

Penniman holds an undergraduate degree in engineering and $\mathrm{Ph}$. D . in behavioral science, and has published over 50 articles and papers in the areas of information systems research, development, and operation.

\section{Register in November}

Preliminary program and registration materials for the Sixth National Conference will be available in November. The registration rate for ACRL members is $\$ 135$ and $\$ 255$ for nonmembers. Additional conference information is available from the ACRL office, (800) 5452433, ext. 2516. 